\title{
Covid-19: Surveys indicate low infection level in community
}

\author{
Jacqui Wise \\ London \\ Just $0.27 \%$ of people-one in 370 - are estimated to have had \\ covid-19 outside of hospitals and care homes in England in the \\ past two weeks, say the preliminary results of a snapshot survey \\ published by the Office for National Statistics (ONS). ${ }^{1}$ \\ The figures were described by England's deputy chief medical \\ officer, Jonathan Van-Tam, as "quite a low level of infection \\ in the community," at the government's daily briefing on 14 \\ May.
}

The survey results come as studies from Spain and France indicate that just $5.0 \%$ and $4.4 \%$ of their populations respectively have ever contracted covid-19, indicating that most people may still be susceptible to infection.

The ONS data show only the number of participants who were positive for covid-19 at the time of swabbing (the positivity rate), not the number of participants who have had covid-19 (the prevalence).

Nicholas Beeching, consultant in infectious diseases at the Liverpool School of Tropical Medicine, told The BMJ, "We need dependable antibody testing of a representative sample of the population to get a real picture of the rates of infection in the country. However, if it turns out that only $5-10 \%$ of the population have been infected with covid-19 then this would be totally inadequate to provide herd immunity as lockdown is released."

The ONS survey was based on self-administered throat and nose swab tests conducted on 10705 people in 5276 households during the two weeks from 27 April to 10 May, and 33 individuals in 30 households tested positive. This suggests that, at any given time during those two weeks, an average of 148 000 people in England had covid-19 (95\% confidence interval 94000 to 222000 ), equating to $0.27 \%$ of England's population $(0.17 \%$ to $0.41 \%)$.

The survey found that people who said they worked in patient facing healthcare roles or resident facing social care roles were more likely to test positive $(1.33 \%)$ than people who reported working in other sectors $(0.22 \%)$.

No evidence was found of differences in the proportions testing positive in different age groups in the survey, which was carried out by Oxford University, Manchester University, and Public Health England.

\section{Repeat tests}

These are the first results from the study, which will be expanded to include 25000 people. Every participant is swabbed once and then invited to have repeat tests every week for the first five weeks and then monthly for 12 months. Adults from 2000 households will also provide a blood sample to determine the proportion of the population that has developed antibodies to covid-19.

Tom Wingfield, honorary consultant physician at the Liverpool School of Tropical Medicine, commented, "Swabbing the nose and throat can be uncomfortable and tricky, especially when self-testing, and it is not clear what the quality of these self-swabs was. In addition, there is not yet enough data to help us to understand how confident we can be that a negative swab means that a person does not currently have covid- 19 .

"False negative rates-when a swab is negative in a person who actually has covid-19 infection-could be influenced by the quality of the swab, laboratory procedures, when the swab was taken within the course of covid-19 illness, and other factors."

Results from the first round of antibody testing in Spain showed that just $5 \%$ of participants had contracted covid- $19 .{ }^{2}$ The study, carried out by the Carlos III Institute of Health and the National Statistics Institute, began on 27 April and tested 60000 people for the presence of antibodies to covid-19.

Infection rates were much higher in Madrid, which had a prevalence of $11.3 \%$. Soria (14.2\%) and Cuenca (13.5\%), in the central regions of Castilla y Leon and Castilla La Mancha, were the provinces with the highest prevalence. The results indicate that 2.3 million of Spain's 45 million population have been affected by the virus-more than 10 times the official count of 230000 cases.

"We have not been surprised" by the results, said Salvador Illa, health minister, at a news briefing. "There is no herd immunity in Spain." He said that the results supported Spain's policy of staggering the release of lockdown.

One problem with the Spanish study is that it used a rapid antibody test, which had a sensitivity of $79 \%$ and specificity of $100 \%$ for $\operatorname{IgG}$ antibodies.

\section{Insufficient immunity}

A modelling study in France, published in Science, ${ }^{4}$ estimated that $4.4 \%$ (range $2.8 \%$ to $7.2 \%$ ) of the population of France (2.8 million people) have been infected. The authors concluded that "population immunity appears insufficient to avoid a second wave if all control measures are released at the end of the lockdown." 
Another modelling paper analysing published local authority data in England up to 23 April has come up with a much higher figure, estimating that $29 \%$ of the population may have already been infected by the covid- 19 virus. ${ }^{5}$ However, that research, published in the International Journal of Clinical Practice, has been criticised for its methodology.

Adam Kucharski, associate professor in infectious disease epidemiology at the London School of Hygiene \& Tropical Medicine, said, "Given how difficult it is to estimate the extent of unreported cases in a population from reported cases alone, it is likely that there is huge uncertainty in the estimates produced by the model used in this paper, and unfortunately this uncertainty is not reflected in the single value quoted."

Beeching said that the widely varying results from different modelling papers showed how difficult it was to get a figure. He added, "On top of this is the worry that antibody levels may be useful diagnostically, but we still don't know if they provide immunity from future infection."

1 Office for National Statistics. Coronavirus (COVID-19) Infection Survey pilot: England, 14 May 2020. Last updated 14 May 2020. https://www.ons.gov.uk/releases/ covid19infectionsurveyenglandprovisionalresults.

2 Instituto de Salud Carlos III. Estudio nacional de sero-epidemiologia de la infeccion por SARS-COV-2 en Espana [National sero-epidemiology study of SARS-COV-2 infection in Spain]. 13 May 2020. https://www.lamoncloa.gob.es/serviciosdeprensa/notasprensa/ sanidad14/Documents/2020/130520-ENE-COVID Informe1.pdf. (In Spanish.)

3 Spanish antibody study suggests $5 \%$ of population affected by coronavirus. Reuters 2020 May 13. https://www.reuters.com/article/us-health-coronavirus-spain/spanish-antibodystudy-suggests-5-of-population-affected-by-coronavirus-idUSKBN22P1IK.

4 Salje $\mathrm{H}$, Kiem C, Lefrancq N, et al. Estimating the burden of SARS-CoV-2 in France. Science 2020 May 13. 10.1126/science.abc3517. https://science.sciencemag.org/content/ early/2020/05/12/science.abc3517.

5 Stedman M, Davies M, Lunt M, Verma A, Anderson SG, Heald AH. A phased approach to unlocking during the COVID-19 pandemic - Lessons from trend analysis. Int J Clin Pract 2020:e13528. 10.1111/ijcp.13528. 32378252

Published by the BMJ Publishing Group Limited. For permission to use (where not already granted under a licence) please go to http://group.bmj.com/group/rights-licensing/ permissions 